\title{
Derailing FELA's Causation Standard: The Supreme Court's Misinterpretation of FELA in McBride and Suggestions to Restrict the Potential for Unlimited Carrier Liability
}

\section{INTRODUCTION}

Both economically and socially, railroads are an integral part of modern America. From the earliest days of rail development in the Northeast $^{1}$ and the connection of the first transcontinental rail route at Promontory Summit, Utah, ${ }^{2}$ to Amtrak $^{3}$ and modern freight transportation, railroads have captured the American imagination ${ }^{4}$ and played a vital role in economic development. ${ }^{5}$ As with many inventions associated with the Industrial Revolution, the development of America's railroad system took an enormous toll on railroad employees and their

\footnotetext{
* Trent R. Byquist. J.D. Candidate 2013, University of Kansas School of Law; B.S. 2010, Kansas State University. I would like to thank Professor Pamela V. Keller for her helpful feedback and the University of Kansas Law Review board and staff for their assistance editing this Note. I would also like to thank Dr. Lou Falkner Williams of Kansas State University's History Department for her encouragement in studying the Supreme Court and assistance developing my research and writing.

1. For an anecdotal description of one of America's earliest railroads in the Northeast portion of the country, see generally HERBERT H. HARWOOD, JR., IMPOSSIBLE CHALLENGE: THE BALTIMORE AND OHIO RAILROAD IN MARYLAND (1979).

2. For a discussion of the completion of the First Transcontinental Railroad, see generally DAVID HAWARD BAIN, EMPIRE EXPRESS: BUILDING THE FIRST TRANSCONTINENTAL RAILROAD 645-72 (1999).

3. See generally Jeffrey J. Amato, Comment, The MTA, It's Not "Going Your Way"Liability of the Metropolitan Transportation Authority Under FELA: Greene v. Long Island R.R., 75 ST. JoHN's L. REV. 113, 125-35 (2001) (discussing the Amtrak and the Metropolitan Transportation Authority's liability under FELA).

4. See, e.g., ReV. W. Awdry, Thomas the TANK Engine: The Complete Collection (Random House Value Publ'g 1997) (1996) (compilation of stories featuring popular children's book character and train "Thomas the Tank Engine"); MAURY KLEIN, UNFINISHED BUSINESS: THE RAILROAD IN AMERICAN LIFE (1994) (collecting articles discussing the importance of the railroad industry in American life); WATTY PIPER, THE LiTTLE ENGINE THAT COULD (1978) (world-famous American children's book using a fictional train to express the importance of positive thinking and perseverance); AYN RAND, ATLAS SHRUGGED (1957) (perennial best-selling American novel that centers on the social and economic importance of the railroad industry).

5. See Leland H. Jenks, Railroads as an Economic Force in American Development, 4 J. ECON. HIST. 1, 10-20 (1944) (discussing railroads' impact on economic development in America).
} 
families in terms of injuries, disabilities, and deaths. ${ }^{6}$ Dismayed by the frequency and severity of injuries railroad employees suffered, ${ }^{7}$ Congress passed the Federal Employers Liability Act (FELA) ${ }^{8}$ in $1908 .{ }^{9}$ FELA's purpose was to compensate railroad employees who were injured as a result of carrier negligence. ${ }^{10}$ By providing a federal statutory tort that relaxed many of the common law restrictions on recovery for carrier negligence, ${ }^{11}$ Congress sought to encourage the railroad industry to improve employee safety by exposing carriers to greater risk of liability. ${ }^{12}$ With a few congressional tweaks, ${ }^{13}$ FELA has remained the statutory mechanism by which employees injured by carrier negligence have asserted claims for damages since $1908 .^{14}$

In perhaps the most consequential FELA case in the statute's history, the United States Supreme Court recently addressed an element under the statute that has long caused confusion. ${ }^{15}$ In CSX Transportation, Inc. $v$. McBride, the Court ruled that FELA does not incorporate proximate cause requirements that exist in nonstatutory tort actions. ${ }^{16}$ Relying on the statute's ambiguous causation language and the fifty-four-year-old case Rogers v. Missouri Pacific Railway Co., ${ }^{17}$ the majority decided that employees injured by railroad negligence may recover damages if carrier negligence played "any part"-no matter how small or remote-in bringing about the injury. ${ }^{18}$ In so doing, the Court concluded that juries

6. See LAWrence M. Friedman, A History of AmEriCAn LAw 223 (3d ed. 2005).

7. William P. Murphy, Sidetracking the FELA: The Railroads' Property Damage Claims, 69 MinN. L. REV. 349, 355 (1985).

8. 45 U.S.C. $\S \S 51-60$ (2006).

9. Federal Employers Liability Act, Pub. L. No. 60-100, 35 Stat. 65 (1908).

10. Murphy, supra note 7, at 355.

11. See Amato, supra note 3, at 117 (discussing common law defenses eliminated by FELA).

12. See Jamison v. Encarnacion, 281 U.S. 635, 640 (1930) (stating that FELA was "intended to stimulate carriers to greater diligence for safety”), superseded by statute, Longshore and Harbor Workers' Compensation Act Amendments of 1984, Pub. L. No. 98-426, 98 Stat. 1639 (1984), as stated in McDermott Int'l, Inc. v. Wilander, 498 U.S. 337, 349 (1991); see also Mondou v. N.Y., New Haven \& Hartford R.R. Co. (Second Employers’ Liability Cases), 223 U.S. 1, 50-51 (1912).

13. See Murphy, supra note 7, at 361-64 (discussing congressional amendments to FELA in 1910 and 1939).

14. See 45 U.S.C. $\S \S 51-60$ (2006) (providing the statutory framework for FELA's federal tort regime); see also Murphy, supra note 7, at 358.

15. See Melissa Sandoval Greenidge, Comment, Getting the Train on the Right Track: A Modern Proposal for Changes to the Federal Employers' Liability Act, 41 MCGEORGE L. REV. 407, 414-18 (2010) (discussing the confusion and difficulty courts have faced in applying a consistent causation standard in FELA cases).

16. 131 S. Ct. 2630, 2634 (2011).

17. 352 U.S. 500 (1957).

18. McBride, 131 S. Ct. at 2634. 
should not be instructed to consider questions encompassing the concept of proximate cause. ${ }^{19}$ Absent such instruction, juries must decide cases without considering whether the injury was within the scope of the risk created by the carrier's negligence; whether the injury was a natural, probable, or foreseeable outcome of the negligence; or whether a superseding or intervening cause led to the employee's injury. ${ }^{20}$ The Court's 5-4 decision in McBride is an erroneous interpretation of FELA's causation standard, as modified by Rogers, for claims involving carrier negligence. And although the dissent was more faithful to FELA's text and history by incorporating a proximate causation standard of some kind, it failed to provide an alternate causation standard.

Part II of this Note begins by examining railroads and railroadrelated accidents before Congress enacted FELA. This section focuses on the state-by-state common law tort system's failure to adequately protect carrier employees from negligence and the dangerous conditions caused by these speeding "iron horses." Next, Part II explores FELA's passage as a response to this problem. It examines the views held by the politicians who enacted the statute and early court cases interpreting its provisions. Part II also discusses the Supreme Court's Rogers decision and subsequent FELA cases, which laid the groundwork for eliminating a proximate cause element in FELA actions. ${ }^{21}$

Finally, Part II examines the accident that gave rise to McBride. It describes the facts surrounding the plaintiff Robert McBride's injuries, the trial where the disputed jury instruction withholding a proximate cause instruction was given, and the subsequent appeals by CSX Transportation, Inc. (CSX). Part II concludes by examining the arguments of the litigants and the positions advocated in amici briefs submitted to the Supreme Court. It includes questions the Justices posed to counsel at oral argument, which shed a great deal of light on the individual Justices' initial inclinations.

Part III of this Note analyzes the outcome in McBride and the rationale of the majority and dissenting opinions. Next, it argues that the Court's erroneous conclusion that proximate cause is irrelevant in FELA decisions threatens to expose railroads to unlimited liability under a "but for” causation standard. Part III proposes a flexible causation standard

19. See id. at 2652 (Roberts, C.J., dissenting).

20. Id.

21. See id. at 2634 (majority opinion) (stating that the holding was "[i]n accord with ... this Court's decision in [Rogers]”). 
that will require plaintiffs to prove proximate cause, while allowing a jurisdiction-by-jurisdiction approach to defining the stringency with which courts should analyze proximate cause. Finally, this Note calls on Congress to amend FELA to include this workable causation standardwhich is similar to the one that was used under FELA for most of its existence-that will appropriately restrict carrier liability while maintaining the statute's remedial goals and "humanitarian purposes."22

\section{BACKGROUND}

\section{A. Railroad Liability in Tort Before FELA}

Before the passage of FELA, rail workers were exposed to enormous hazards in the workplace from which the prevailing common law tort system provided little protection. ${ }^{23}$ During an address in 1889, President Benjamin Harrison reminded Congress of the astonishing threat of injury that rail workers in the late Nineteenth Century faced. ${ }^{24}$ In calling for protective federal legislation, President Harrison chastised Congress that "[i]t is a reproach to our civilization that any class of American workmen should, in the pursuit of a necessary and useful vocation, be subjected to a peril of life and limb as great as that of a soldier in time of war." 25 President Harrison was not merely hyperbolizing to push for desired legislation. One year before Harrison's address, "the odds against a railroad brakeman's dying a natural death were almost four to one.” ${ }^{26}$ According to the Interstate Commerce Commission, 2,660 railway employees were killed and 26,140 railway employees injured during a one-year period in the early 1890s. ${ }^{27}$

Despite these well-known hazards, the state common law system was surprisingly nonresponsive to employee tort claims for employer negligence. ${ }^{28}$ In many cases, employees who suffered severe injuries or

22. Consol. Rail Corp. v. Gottshall, 512 U.S. 532, 542 (1994).

23. See Norfolk S. Ry. Co. v. Sorrell, 549 U.S. 158, 179 (2007) (Ginsburg, J., concurring) (citing Gottshall, 512 U.S. at 542; Wilkerson v. McCarthy, 336 U.S. 53, 68 (1949) (Douglas, J., concurring)) (noting Congress's dissatisfaction with the common law tort system's response to rail accidents prior to FELA).

24. See Johnson v. S. Pac. Co., 196 U.S. 1, 19 (1904).

25. Id.

26. Bhd. of R.R. Trainmen v. Va. ex rel. Va. State Bar, 377 U.S. 1, 3 (1964).

27. Johnson, 196 U.S. at 19.

28. See Murphy, supra note 7, at 356 ("Congress enacted the Federal Employer's Liability Act 'to give relief against the rigors of the common law.”' (quoting 40 CONG. REC. 4608 (1905) (statement of Rep. Flood))). 
even death faced unsympathetic judges who dismissed their claims before trial, directed verdicts in favor of the defendant railroads, or overturned judgments in the plaintiffs' favor on appeal. ${ }^{29}$ Additionally, many strict common law rules regarding plaintiffs' contributory negligence, their alleged assumption of risk, and the fellow servant rule often operated to bar recovery by an injured worker. ${ }^{30}$ In 1908, the year Congress passed FELA, the Senate Committee on Education and Labor recognized that the state-by-state common law approach placed a disproportionate share of the burden for railroad accidents on the backs of railroad laborers. ${ }^{31}$ This inequitable situation led many in Congress and the federal government to echo President Harrison's call for a federal compensatory scheme that would help ensure workers injured by railroad negligence received adequate compensation. ${ }^{32}$

\section{B. FELA and Early FELA Cases}

Congress passed FELA in 1908. ${ }^{33}$ Although the 1908 law and its subsequent amendments are still largely the provisions that govern railroad negligence today, the 1908 statute was not Congress's first attempt to expand carrier liability with a federal tort. ${ }^{34}$ The precursor to FELA was passed in 1906, and it contained many of the provisions eventually incorporated into FELA. ${ }^{35}$ Although the interstate nature of railroads appear to make them the quintessential target of regulation under Congress's Commerce Clause authority, ${ }^{36}$ the Supreme Court in Howard v. Illinois Central Railroad Co. effectively gutted the 1906 statute, ruling that it impermissibly infringed on purely intrastate activities. $^{37}$ Dicta in Howard, however, suggested that with some

29. See, e.g., Johnson v. S. Pac. Co., 117 F. 462, 472 (8th Cir. 1902) (affirming directed verdict in personal injury tort claim), rev'd, 196 U.S. 1 (1904); Boland v. Louisville \& N.R. Co., 96 Ala. 626, 632-35 (1892) (affirming judgment for defendant railroad after trial judge refused to instruct the jury regarding the railroad's knowledge that plaintiff was unfamiliar with the employment task assigned); Mich. Cent. R. Co. v. Smithson, 7 N.W. 791, 795 (Mich. 1881) (reversing jury verdict in favor of injured plaintiff).

30. See Consol. Rail Corp. v. Gottshall, 512 U.S. 532, 542-43 (1994).

31. S. REP. No. 60-460, at 1-3 (1908).

32. See Murphy, supra note 7, at 359.

33. Federal Employers Liability Act, Pub. L. No. 60-100, 35 Stat. 65 (1908).

34. For a discussion of FELA's predecessor, passed in 1906, see generally Murphy, supra note 7, at 355-58.

35. See id.

36. U.S. CONST. art. I, § 8, cl. 3

37. 207 U.S. $463,502-04$ (1908). 
changes, the Court would be willing to acquiesce in a federal tort scheme to regulate railroad employee safety. ${ }^{38}$ Acting on this invitation and with the encouragement of progressive Republican President Theodore Roosevelt, Congress enacted FELA the same year as the Howard decision, invalidating the prior law. ${ }^{39}$ FELA built on Congress's earlier attempt to abrogate the most defense-friendly rules that had developed in the common law regarding employer negligence. ${ }^{40}$ In addition to the provisions that expressly abrogate otherwise applicable common law doctrines, FELA provides that:

Every common carrier by railroad ... shall be liable in damages to any person suffering injury while he is employed by such carrier ... or, in case of the death of such employee, to his ... personal representative, for the benefit of the surviving widow ... and children of such employee ... for such injury or death resulting in whole or in part from the negligence of any of the officers, agents, or employees of such carrier .... ${ }^{41}$

With this broad standard of causation, Congress greatly improved injured rail workers' chances of recovering for negligence-related injuries suffered in the workplace. In the words of Justice William O. Douglas, Congress "designed [FELA] to put on the railroad industry some of the cost for the legs, eyes, arms, and lives which it consumed in its operations." 42 Although it is clear Congress sought to put an increased burden on the railroads for injuries that occurred as a result of railroad negligence, it is not clear from early cases and contemporary statements that FELA abrogated the requirement of proximate cause between the negligence and harm.

State and federal courts have concurrent jurisdiction over claims under FELA $^{43}$ but its substance is solely a matter of federal law. ${ }^{44}$ Accordingly, FELA preempts state law tort claims for rail carrier

38. See id. at 504 (conceding that the statute "embraces [some] subjects within the authority of Congress to regulate commerce").

39. Murphy, supra note 7, at 359 (quoting 42 CONG. REC. 1347 (1908) (special message of President Theodore Roosevelt)).

40. See CSX Transp., Inc. v. McBride, 131 S. Ct. 2630, 2646 (2011) (Roberts, C.J., dissenting); see also Norfolk S. Ry. Co. v. Sorrell, 549 U.S. 158, 168 (2007); Consol. Rail Corp. v. Gottshall, 512 U.S. 532, 542-43 (1994).

41. 45 U.S.C. $\S 51$ (2006).

42. Wilkerson v. McCarthy, 336 U.S. 53, 68 (1949) (Douglas, J., concurring).

43. 45 U.S.C. § 56.

44. Sorrell, 549 U.S. at 165. 
negligence. ${ }^{45}$ In contrast to no-fault damages statutes, such as workers' compensation, FELA is a negligence statute. ${ }^{46}$ As the statutory language indicates, recovery is premised on the "negligence of . . . such carrier." 47 The majority of early cases under FELA required that the plaintiff satisfy a proximate causation standard. ${ }^{48}$ In fact, the Supreme Court applied a proximate causation standard in more than fifteen FELA cases before Rogers. $^{49}$ Two FELA cases to reach the Supreme Court following its passage-Norfolk \& Western Railway Co. v. Earnest ${ }^{50}$ and St. Louis, Iron Mountain \& Southern Railway v. McWhirter ${ }^{51}$ - explicitly applied a proximate causation standard. ${ }^{52}$ And Congress was apparently unconcerned that courts were applying proximate cause in FELA cases. Despite passing significant amendments to the statute in $1910^{53}$ and $1939,{ }^{54}$ Congress declined to change the causation language used in the initial law. ${ }^{55}$

Following the 1939 amendments, the Supreme Court reaffirmed the interpretation of causation under FELA as including a proximate cause element. $^{56}$ In Brady v. Southern Railway Co., the Supreme Court affirmed a North Carolina decision denying recovery for failure to satisfy proximate cause. ${ }^{57}$ Although Brady was decided by a 5-4 vote, the dissent also recognized that proximate cause was "the meaning Congress

45. Id.

46. See 45 U.S.C. $\S 51$.

47. Id.

48. See Sorrell, 549 U.S. at 173-74 (Souter, J., concurring) ("[T]hroughout the half-century between FELA's enactment and the decision in Rogers, we consistently recognized and applied proximate cause as the proper standard in FELA suits.”).

49. Petition for Writ of Certiorari at 17, CSX Transp., Inc. v. McBride, 131 S. Ct. 2630 (2011) (No. 10-235), 2010 WL 3267817, at *17.

50. 229 U.S. 114 (1913).

51. 229 U.S. 265 (1913).

52. Earnest, 229 U.S. at 118-19 (finding that the jury was correctly instructed that, if the engineers' failure to warn "was the proximate cause of the accident, then [you] must find for the plaintiff”); McWhirter, 229 U.S. at 280 (holding "it must be shown” that the alleged negligent act was the proximate cause of the plaintiff's injuries).

53. Federal Employers Liability Act, Pub. L. No. 61-117, 36 Stat. 291 (1910) (codified at 45 U.S.C. § 56 (2006)).

54. Federal Employers Liability Act, Pub. L. No. 76-382, 53 Stat. 1404 (1939) (codified at 45 U.S.C. § 54 (2006)).

55. See Murphy, supra note 7, at 361-64 (describing the 1910 and 1939 amendments to FELA, which did not alter the causation standard).

56. See Brady v. S. Ry. Co., 320 U.S. 476, 484 (1943), abrogated by CSX Transp., Inc., v. McBride, 131 S. Ct. 2630 (2011).

57. See id. at 484 ("The carrier's negligence must be a link in an unbroken chain of reasonably foreseeable events.”). 
intended when it made railroads liable for the injury or death of an employee 'due to' or 'resulting in whole or in part from' the railroad's negligence." 58 The Court later, in 1949, confirmed the apparently unquestioned and uncontroversial position that proximate cause was a mandatory element in FELA claims. ${ }^{59}$ In both federal and state cases under FELA before Rogers, not only was proximate cause an element of the claims, but any argument to the contrary apparently received very little or no attention. In Rogers, however, the Court's decision shed considerable doubt on the Court's understanding of FELA's causation language.

\section{Rogers and Subsequent FELA Cases}

\section{Rogers v. Missouri Pacific Railroad Co.}

In July 1951, James Rogers was employed as a laborer by the Missouri Pacific Railroad Company. ${ }^{60}$ While working alongside a double-track line that Missouri Pacific owned, Rogers's foreman assigned him the duty of burning off weeds and vegetation beside the track. ${ }^{61}$ Rogers was given a "crude hand torch" and instructed to burn vegetation growing on a steep incline that sloped up away from the double-track line. ${ }^{62}$ The foreman additionally instructed Rogers to stop burning the vegetation when a train approached on the line and visually inspect the train's journals, or bearings, for "hotboxes."63 When Rogers heard the whistle of an approaching train, he retreated from the line as instructed. ${ }^{64}$ The passing train, however, fanned some remaining flames, which quickly spread and enveloped the area surrounding Rogers. ${ }^{65}$ Rogers attempted to flee the dangerous area, but while running along the steep embankment and through thick smoke, he slipped on loose gravel covering the slope. ${ }^{66}$ The subsequent fall caused Rogers personal injuries, for which he sued Missouri Pacific under FELA in the St. Louis

\footnotetext{
58. Id. at 489 (Black, J., dissenting).

59. See Urie v. Thompson, 337 U.S. 163, 177 (1949)

60. Rogers v. Mo. Pac. R.R. Co., 352 U.S. 500, 501 (1957).

61. Id.

62. Id. at 502

63. Id.

64. Id.

65. Id.

66. Id. at $502-03$.
} 
Circuit Court. ${ }^{67}$ After a jury returned a verdict in Rogers's favor and awarded him \$40,000 in damages, Missouri Pacific appealed to the Missouri Supreme Court. ${ }^{68}$

Rogers argued at trial that his injury was caused by Missouri Pacific's failure to exercise ordinary care in instructing him to burn so close to the rail line. ${ }^{69}$ Rogers further alleged that the burning method was unreasonably dangerous. ${ }^{70}$ Although the jury found that Missouri Pacific was negligent and awarded Rogers damages, the Supreme Court of Missouri reversed for lack of evidence to support the jury's liability finding. ${ }^{71}$ The Missouri Supreme Court—again applying a form of proximate cause - held that "the fire ... was something extraordinary, unrelated to, and disconnected from the incline of the gravel at the culvert." ${ }^{72}$ Consequently, a unanimous court reversed the jury's award. ${ }^{73}$ Rogers appealed the Missouri Supreme Court's decision to the United States Supreme Court, and the Court granted certiorari to determine whether the reversal invaded the jury's proper function under FELA. ${ }^{74}$

The Supreme Court ruled 6-3 that the Missouri Supreme Court had improperly reversed the jury's finding of actionable negligence by Missouri Pacific. ${ }^{75}$ Although welcome news for Rogers, the decision cast doubt on the previously settled question of FELA's caused "in whole or in part” language. Justice William Brennan's opinion in Rogers injected considerable uncertainty into analyzing claims under FELA. The Court concluded that the Missouri Supreme Court's opinion was susceptible to "two potential readings" but under either understanding it was incorrect to set aside the jury's verdict. ${ }^{76}$ The Court first rejected the Missouri Supreme Court's ruling that Rogers's actions were as a matter of law "the sole cause of his mishap." the future understanding of the causation requirement under FELA, the Court concluded that the employer's negligence need not be a more-

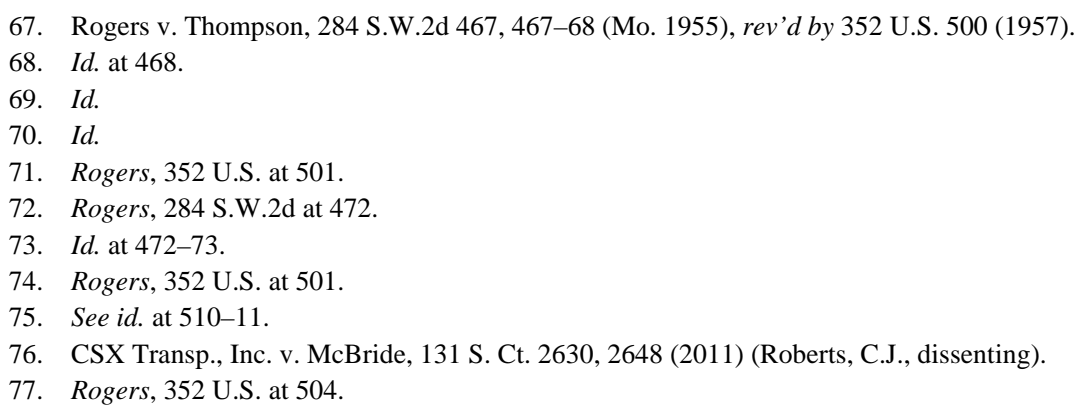


probable cause of Rogers's injuries than his own actions. ${ }^{78}$ Accordingly, the Court held that the Missouri Supreme Court erred in reversing the jury verdict and reversed and remanded for proceedings in accord with the opinion. ${ }^{79}$

In concluding that it was irrelevant whether the employer or employee's actions were the more-probable cause of the plaintiff's injuries, the Court failed to specify whether it was addressing solely the statutory contributory fault provision in FELA or fundamental understandings of proximate cause. Consequently, the Court's language that the only question for the jury was whether "employer negligence played any part, even the slightest, in producing the injury" ${ }^{\text {" }}$ led many courts to effectively conclude that proximate cause was no longer a requirement under FELA. ${ }^{81}$ Moreover, many courts that still recognized a proximate causation standard of sorts diluted its requirements to such a degree that there was substantively no proximate cause-as it is known under common law standards-required in FELA cases. ${ }^{82}$ Despite this widespread interpretation of Rogers, numerous courts and several Supreme Court justices still believed that Rogers did not alter FELA's proximate cause requirement. ${ }^{83}$ Accordingly, confusion regarding the causation standard required for recovery under FELA permeated decisions under the statute following Rogers.

\section{Supreme Court Cases Struggling to Apply FELA Post-Rogers}

Although McBride was the first landmark decision interpreting FELA since Rogers, ${ }^{84}$ several cases reached the Court in the interim and

78. See McBride, 131 S. Ct. at 2638; Rogers, 352 U.S. at 505-06.

79. Rogers, 352 U.S. at 511.

80. Id. at 506 .

81. See, e.g., Summers v. Mo. Pac. R.R. Sys., 132 F.3d 599, 606 (10th Cir. 1997) (“[T]he Supreme Court definitely abandoned [the proximate cause] approach in [Rogers] . ...”); Oglesby v. S. Pac. Transp. Co., 6 F.3d 603, 609 (9th Cir. 1993) (holding and noting agreement in other courts that proximate cause is no longer required in FELA actions).

82. See, e.g., Sea-Land Serv., Inc. v. Sellan, 231 F.3d 848, 851 (11th Cir. 2000) (stating under FELA that employer will be liable if negligence "played any part" in the injury); Ulfik v. Metro-N. Commuter R.R., 77 F.3d 54, 58 (2nd Cir. 1996) (stating that a "relaxed standard of proof" applies to causation in FELA cases); Moody v. Me. Cent. R.R. Co., 823 F.2d 693, 695-96 (1st Cir. 1987) ("We recognize the considerably relaxed standard of proof in FELA cases.”).

83. See Norfolk S. Ry. Co. v. Sorrell, 549 U.S. 158, 172-76 (2007) (Souter, J., concurring) ("The absence of any intent to water down the common law requirement of proximate cause is evident from the cases on which Rogers relied.").

84. Victor E. Schwartz, The Supreme Court Meets Civil Justice Issues: A Most Unusual Term, HERITAGE FOUND. (Aug. 29, 2011), http://www.heritage.org/research/reports/2011/08/the-supreme- 
demonstrated the confusion wrought by the Rogers decision. ${ }^{85}$ Rogers was an important element in the Court's decision in McBride, and the Court's inability to successfully apply FELA after Rogers is indicative of the decision's analytical problems. Moreover, several FELA decisions between Rogers and McBride demonstrated the problems inherent in Rogers's confusion-inducing standard. Most prominent among these confused decisions are Consolidated Rail Corp. v. Gottshall ${ }^{86}$ and Norfolk Southern Railway Co. v. Sorrell. ${ }^{87}$

\section{a. Consolidated Rail Corp. v. Gottshall}

The Court granted certiorari in Gottshall to determine whether a claim for the negligent infliction of emotional distress was cognizable under FELA. ${ }^{88}$ Accordingly, Justice Thomas's majority opinion did not directly address the proximate causation standard articulated in Rogers. ${ }^{89}$ The dispute in Gottshall centered on the general issue of the extent to which common law principles remained applicable under the statutory tort regime FELA created. ${ }^{90}$ Because proximate causation is a hallmark of the common law tort system, ${ }^{91}$ the interpretation of common law standards in Gottshall shed considerable light on the importance of such principles under FELA. The Gottshall Court held that "although common-law principles are not necessarily dispositive of questions arising under FELA, unless they are expressly rejected in the text of the statute, they are entitled to great weight in our analysis." ${ }^{22}$ Emphasizing the common law's importance, the Court concluded that an employee could maintain an action for negligent infliction of emotional distress

court-meets-civil-justice-issues-a-most-unusual-term.

85. See, e.g., Consol. Rail Corp. v. Gottshall, 512 U.S. 532, 542-44 (1994) (noting that the Rogers Court found a relaxed standard for causation).

86. 512 U.S. 532 (1994).

87. 549 U.S. 158 (2007).

88. Gottshall, 512 U.S. at 535.

89. See id. at 543 (discussing but not scrutinizing the "relaxed standard of causation" articulated in Rogers).

90. See id. at 543-44 (stating FELA is founded on common law concepts of negligence but subject to congressional qualifications).

91. See CSX Transp., Inc. v. McBride, 131 S. Ct. 2630, 2645 (2011) (Roberts, C.J., dissenting) ("Recovery for negligence has always required a showing of proximate cause.”).

92. Gottshall, 512 U.S. at 544. 
under FELA and that the "zone of danger" test was the appropriate standard for that particular injury. ${ }^{93}$

Even though it did not rely on Rogers's holding in Gottshall, the Court emphasized the unworkable nature of foreseeability as a test for liability under FELA. ${ }^{94}$ Concurring, Justice Souter wrote separately to "make explicit ... the Court's duty . . . in interpreting FELA."95 Justice Souter argued that this duty was to "develop a federal common law of negligence under FELA, informed by reference to the evolving common law."96 Justice Souter ultimately concluded that the Court met its obligation, and he joined the majority opinion. ${ }^{97}$ In her dissent, however, Justice Ginsburg argued that the Court required an overly restrictive standard by imposing the "zone of danger" test. ${ }^{98}$ The defects in Rogers's standard and the dicta used therein are particularly noticeable in Ginsburg's dissent. Justice Ginsburg relied on the remedial nature of FELA and the conclusion that "FELA was designed to provide a federal 'statutory negligence action ... significantly different from the ordinary common-law negligence action.",99 Her dissent, joined by Justices Stevens and Blackmun, concluded that the correct common law test was not as easily discernible as the Court concluded. ${ }^{100}$ The three dissenting Justices would have allowed the lower courts to develop a more liberal standard for negligent infliction of emotional distress claims. ${ }^{101}$

Justice Ginsburg's dissent in Gottshall indicated her inclination to scuttle common law rules in favor of broad, sweeping protection for injured rail workers. Her conclusion that requiring consistency with the common law was "odd" foretold her desire to expand FELA protection regardless of what common law principles generally applied in $1908 .{ }^{102}$

93. See id. at 557 ("[W]e conclude that the policy considerations of the common law as they are embodied in the zone of danger test best accord with the concerns that have motivated our FELA jurisprudence.”).

94. See id. at 553-55 (discussing the foreseeability of the worker's injury to the defendant rail company).

95. Id. at 558 (Souter, J., concurring).

96. Id.

97. Id. at 559 .

98. See id. at 559-60 (Ginsburg, J., dissenting).

99. Id. at 560 (alteration in original) (quoting Rogers v. Mo. Pac. R.R. Co., 352 U.S. 500, 50910 (1957)).

100. See id. at 571-72 (criticizing the majority's rejection of the approach "thoughtfully developed and comprehensively explained” by the lower court).

101. See id. at 572 (noting that the zone of danger test "leaves severely harmed workers remediless”).

102. See id. at 571 . 
Although the majority of the Court agreed that the common law required the "zone of danger" test, Justice Ginsburg rejected a strict application of a singular common law, noting that " $[\mathrm{t}] \mathrm{he}$ common law is not a brooding omnipresence in the sky."103 The dissent in Gottshall illustrated the Court's lack of uniformity regarding the extent to which common law principles remained applicable in FELA cases after Rogers. Several years after Gottshall, the issue of the continuing applicability of common law principles in FELA cases reemerged in Sorrell. ${ }^{104}$

\section{b. Norfolk Southern Railway Co. v. Sorrell}

In Sorrell, the Court confronted the question of whether a different proximate causation standard should apply in FELA cases involving a plaintiff's contributory negligence. ${ }^{105}$ The Court unanimously rejected the lower court's application of a different causation standard for claims involving contributory negligence. ${ }^{106}$ Despite the unanimity in the outcome, the Court again split sharply in rationale. ${ }^{107}$ In fact, Sorrell is most important for Justices Ginsburg and Souter's concurring opinions that debated the proximate causation standard in FELA cases as modified by Rogers. ${ }^{108}$ Justice Ginsburg concurred only in the outcome of the case and filed a concurring opinion emphasizing that the Court's holding was only relevant to the narrow issue that garnered a majority. ${ }^{109}$ Justice Ginsburg's concurrence was obviously directed at Justice Souter's concurrence-joined by Justices Scalia and Alito-that argued Rogers "did not address, much less alter, existing law governing the degree of causation necessary for redressing negligence."110 Justice Souter's concurrence specifically criticized the attempts by some courts to read Rogers as "smuggl[ing] proximate cause out of ... FELA.""111 True to his reputation as a judicial minimalist, ${ }^{112}$ Chief Justice Roberts's majority

\footnotetext{
103. Id. at 571 n.4 (quoting S. Pac. Co. v. Jensen, 244 U.S. 205, 222 (1917) (Holmes, J., dissenting)) (internal quotation marks omitted).

104. See 549 U.S. 158, 160 (2007).

105. Id.

106. Id. at 159 .

107. Compare id. at 172 (Souter, J., concurring), with id. at 177 (Ginsburg, J., concurring).

108. See id. at 172 (Souter, J., concurring) (noting that Rogers did not intend to "water down" the proximate cause requirement); id. at 177 (Ginsburg, J., concurring) (noting the "relaxed" causation standard for FELA cases).

109. See id. at 177 (Ginsburg, J., concurring).

110. Id. at 173 (Souter, J., concurring).

111. Id. at 173 n.*

112. See generally David Von Drehle, The Incredibly Shrinking Court, TimE (Oct. 11, 2007),
} 
opinion did not reach the question of Rogers's ultimate impact on the proximate causation standard under FELA. ${ }^{113}$ The battling concurrences of Justices Souter and Ginsburg, however, were clearly meant to shape the debate for a future case determining the extent to which Rogers changed the proximate cause requirement in FELA.

After admonishing the lower courts for reading Rogers too broadly, Justice Souter emphasized the continued applicability of common law principles-including proximate cause-in federal tort cases. ${ }^{114}$ The concurrence continued by acknowledging the difficulty caused by Rogers's oblique dicta that seemed to suggest that the proximate cause requirement had been lowered or abolished. ${ }^{115}$ Specifically, Justice Souter noted that "the statement in Rogers that a case must go to a jury where 'the proofs justify with reason the conclusion that employer negligence played any part, even the slightest, in producing the injury or death for which damages are sought'” caused courts great difficulty when grappling with the degree of causation required post-Rogers. ${ }^{116}$ Instead of reading this language as a broad statement regarding causation under FELA, Justice Souter's concurrence sought to cabin its applicability to cases of contributory negligence-the issue before the Court in Rogers. ${ }^{117}$

While Justice Souter advocated limiting Rogers, Justice Ginsburg wrote separately to emphasize that Sorrell did not reach that issue. ${ }^{118}$ She emphasized that the Court's Sorrell opinion did nothing to alter the "relaxed causation" standard announced in Rogers. ${ }^{119}$ Because she was concurring in the judgment alone, Justice Ginsburg did not explicitly announce her view on the issue of proximate cause under FELA, but in retrospect, it appears from her positions in Gottshall and Sorrell that she believed common law conceptions of proximate cause were no longer

\footnotetext{
http://www.time.com/time/magazine/article/0,9171,1670489,00.html (discussing Chief Justice John Roberts's reputation for deciding cases on the narrowest permissible grounds).

113. Sorrell, 549 U.S. at 171-72 (majority opinion) ("The question presented in this case is a narrow one, and we see no need to do more than answer that question in today's decision.”).

114. Id. at 173-74 (Souter, J., concurring).

115. See id. at 175 .

116. Id. (quoting Rogers v. Mo. Pac. R.R. Co., 352 U.S. 500, 506 (1957)).

117. See id. at $175-76$.

118. See id. at 177 (Ginsburg, J., concurring) ("The Court today holds simply and only that in cases under [FELA], railroad negligence and employee contributory negligence are governed by the same causation standard.”).
}

119. Id. at 178 
required. ${ }^{120}$ Furthermore, she spent considerable time listing the policy considerations that supported finding that FELA contains a more relaxed proximate causation standard. ${ }^{121}$ Most prominent among these considerations was the legislative history expressing concern for the plight of injured rail workers and the difficulty of appropriately instructing juries as to the meaning and requirements of proximate cause. $^{122}$ The two concurring opinions in Sorrell staked out opposing points of view regarding proximate cause under FELA, and McBride provided the Court with the necessary case in which to settle the dispute.

D. McBride v. CSX Transportation, Inc.

1. The Accident

CSX employed plaintiff Robert McBride as a locomotive engineer from 1999 until 2004. ${ }^{123}$ In early 2004, McBride was assigned to a run on a train that was powered by five locomotives. ${ }^{124}$ The locomotive McBride was to operate utilized a dual braking system that required the engineer to operate an "independent brake" that the engineer controlled by hand and "actuated by pressing a button on the side of the brake handle."125 Before the run, McBride approached his supervising engineer to express concerns about the safety of the train he would be operating and his lack of experience switching with an independent brake. $^{126}$ The supervising engineer, however, instructed McBride to operate the train despite his concerns. ${ }^{127}$

McBride complied with this request. ${ }^{128}$ During the eight hour run, McBride operated the independent brake "the whole time." 129 When McBride reached to grab the independent brake in anticipation of an upcoming stop toward the end of the run, his hand hit the brake handle,

\footnotetext{
120. See id. at 177-82 (discussing the limited nature of the Court's holding while not setting forth an alternative standard of causation).

121. Id. at $178-80$.

122. Id

123. McBride v. CSX Transp., Inc., 598 F.3d 388, 389 (7th Cir. 2010), aff'd, 131 S. Ct. 2630 (2011).

124. Brief for Petitioner at 5, CSX Transp., Inc. v. McBride, 131 S. Ct. 2630 (2011) (No. 10235), $2011 \mathrm{WL} 141225$, at *5 [hereinafter Brief for CSX].

125. Id.

126. McBride, 598 F.3d at 390.

127. Id.

128. Id.

129. Id.
} 
[Vol. 61

which caused significant pain and swelling. ${ }^{130}$ McBride described the pain as feeling "like somebody threw gas on my hand and set it afire."131 The injuries to McBride's hand required two surgeries and physical therapy. ${ }^{132}$ As a result of his injuries, McBride sued CSX under FELA alleging that the repeated switching had fatigued his hand, thereby causing the injury. ${ }^{133}$

\section{Trial}

McBride asserted negligence on the theory that CSX was negligent in configuring the trains so that an engineer would be required to repeatedly use the actuator button on the independent brake for an extended period of time. ${ }^{134}$ Additionally, McBride alleged that CSX was negligent for failing to train him to operate the equipment. ${ }^{135}$ At trial, McBride and his expert witness both testified that their primary concern with the configuration of the trains was the increased risk of derailment or collision. ${ }^{136}$ Neither witness testified as to the foreseeability of McBride's ultimate injury. ${ }^{137}$ The direct and foreseeable nature of McBride's injury-typically required to satisfy common law proximate cause - was not at all clear from the evidence and testimony at trial. ${ }^{138}$

At the conclusion of the evidence, the judge instructed the jury regarding McBride's causation burden in accordance with the Seventh Circuit's Pattern Instruction. ${ }^{139}$ The instruction stated in pertinent part that 'Defendant 'caused or contributed to' Plaintiff's injury if Defendant's negligence played a part—no matter how small-in

\footnotetext{
130. Brief for CSX, supra note 124, at 5-6.

131. McBride, 598 F.3d at 390.

132. Id.

133. Brief for CSX, supra note 124, at 6 .

134. McBride, 598 F.3d at 390

135. CSX Transp., Inc. v. McBride, 131 S. Ct. 2630, 2635 (2011).

136. See Brief for CSX, supra note 124, at 6.

137. Id. at 6-7.

138. See id. (describing McBride's theory).

139. See id. at 9-10. The pattern instruction states in full:

Defendant 'caused or contributed to' Plaintiff's injury if Defendant's negligence played a part—no matter how small—in bringing about the injury. [There can be more than one cause contributing to an injury]. The mere fact that an injury occurred does not necessarily mean that the injury was caused by negligence.

Fed. Civ. Jury Instructions of the Seventh Circuit 9.02 (2009) (alteration in original), available at http://www.Ca7.uscourts.gov/Pattern_Jury_Instr/7th_civ_instruc_2009.pdf.
} 
bringing about the injury." ${ }^{140}$ CSX objected to this instruction, arguing that it unduly relaxed the proximate causation standard under FELA so as to render it nonexistent. ${ }^{141}$ CSX countered with its own causation instruction that read in pertinent part: "In order to establish that an injury was caused by the defendant's negligence, the plaintiff must show that (i) the injury resulted 'in whole or in part' from the defendant's negligence, and (ii) the defendant's negligence was the proximate cause of the injury."142 Even though CSX's requested instruction included the statutory language from FELA, the trial court rejected the railroad's proffered instruction and charged the jury in accordance with the Seventh Circuit's model instruction. ${ }^{43}$ Relying on the pattern instruction regarding the applicable causation standard, the jury awarded McBride damages of $\$ 275,000$, which the court reduced by $33 \%$ to account for the jury's finding of McBride's negligence. ${ }^{144}$ CSX moved for a new trial. ${ }^{145}$ The trial court overruled CSX's motion because "Plaintiff put forth sufficient evidence from which a jury could conclude that Defendant was negligent and that such negligence caused Plaintiff's injuries," ${ }^{146}$ and CSX appealed. ${ }^{147}$

\section{CSX's Appeal to the Seventh Circuit}

CSX appealed to the United States Court of Appeals for the Seventh Circuit, arguing that FELA required proof of proximate cause by the claiming party and that the trial court's instruction failed to satisfy this requirement. ${ }^{148}$ The Seventh Circuit rejected this argument, but in so doing, expressed a surprising amount of sympathy with CSX's position. ${ }^{149}$ The opinion noted that the three-justice concurrence from Sorrell had "considerable force," concurrence as an authoritative pronouncement on the muddled area of

\footnotetext{
140. McBride v. CSX Transp., Inc., 598 F.3d 388, 391 (7th Cir. 2010); Fed. Civ. Jury Instructions of the Seventh Circuit 9.02, supra note 139.

141. See McBride, 598 F.3d at 391 (noting that CSX cited Sorrell in support of its position).

142. Id.

143. Id

144. McBride v. CSX Transp., Inc., No. 06-CV-1017-JPG, 2008 WL 4185933, at *1 (S.D. Ill. Sept. 8, 2009).

145. Id.

146. Id.

147. McBride, 598 F.3d at 389.

148. See Brief for CSX, supra note 124, at 10.

149. See id.

150. McBride, 598 F.3d at 404.
} 
law. ${ }^{151}$ Instead, because "the Supreme Court did not address, much less decide, the issue that CSX would have [the court of appeals] decide,",152 the Seventh Circuit noted that "a circuit [court] must not anticipate future changes in jurisprudential course by the Supreme Court of the United States; it is the task of the circuit judge to apply established doctrine." Of additional concern to the appellate court was the impact that a reversal might have on how consistently FELA is applied in federal court. ${ }^{154}$ The court noted approvingly that the current causation standard under FELA accorded with all of the other federal circuits. ${ }^{155}$ In addition to exercising deference to Supreme Court precedent-although it was admittedly precedent of dubious reliability - the Seventh Circuit avoided creating a split in the law between circuits and affirmed the jury's verdict, holding that the instruction that effectively eliminated a proximate cause element under FELA was correct. ${ }^{156}$ Accordingly, the appellate court found that "the jury instructions 'correctly and completely informed the jury of the applicable law.","157

\section{E. The Supreme Court's Decision in McBride}

As it does with many landmark decisions, the Supreme Court announced the McBride decision only days before the end of the Court's term in June 2011. ${ }^{158}$ Although the 5-4 decision split along mostly partisan lines, there was a noticeable deviation. ${ }^{159}$ Justice Thomas effectively cast the deciding vote in McBride by voting with Justices Ginsburg, Breyer, Sotomayor, and Kagan to affirm the Seventh Circuit's decision. ${ }^{160}$ In dissent, Chief Justice Roberts was joined by Justices Scalia, Kennedy, and Alito in voting to reverse the Seventh Circuit's decision and require a degree of proximate cause in actions under FELA. ${ }^{161}$ After voicing her opinion in Sorrell that FELA, as interpreted

\footnotetext{
151. Id. at $404-05$.

152. Id. at 404 .

153. Id. at 405 (quoting Nanda v. Bd. of Trs. of the Univ. of Ill., 312 F.3d 852, 854 (7th Cir. 2002)).

154. Id. at $405-06$.

155. Id. at 405 .

156. Id. at $405-06$.

157. Id. at 406 (quoting Huff v. Sheahan, 493 F.3d 893, 899 (7th Cir. 2007)).

158. See CSX Transp., Inc. v. McBride, 131 S. Ct. 2630, 2630 (2011).

159. Schwartz, supra note 84 (noting that majority included "conservative” Justice Thomas and "four far more liberal Justices").

160. McBride, 131 S. Ct. at 2634.

161. Id. at 2645 (Roberts, C.J., dissenting).
} 
by Rogers, effectively eliminated a proximate cause requirement for injury, ${ }^{162}$ Justice Ginsburg's vote in McBride was unsurprising. With four colleagues accepting her position, Justice Ginsburg wrote the majority opinion in McBride that effectuated her earlier position for claims under FELA. ${ }^{163}$ Likewise, the votes of Justices Scalia and Alito were predictable given their agreement with Justice Souter's concurrence in Sorrell. ${ }^{164}$

\section{ANALYSIS}

\section{A. Justice Ginsburg's Majority Opinion}

Justice Ginsburg's majority opinion in McBride was the culmination of her longstanding advocacy for liberalizing the causation requirements under FELA. With the five votes necessary for a majority, Justice Ginsburg's relaxed causation standard under FELA and Rogers became the authoritative interpretation of FELA, binding on both state and federal courts throughout the United States. ${ }^{165}$ The decision in McBride will have an enormous impact on common rail carrier liability in the United States. To understand the extent of its impact, one must first understand Justice Ginsburg's rationale. The majority opinion relied primarily on Rogers as the "comprehensive statement" 166 of FELA and the ordinary understanding of FELA's causation language to arrive at the Court's outcome. ${ }^{167}$ Beyond the regular canons of statutory interpretation, Justice Ginsburg also reopened her previous concerns expressed in Sorrell regarding the difficulty that juries have in applying proximate cause $\mathrm{e}^{168}$ and the lack of any "absurd or untoward award[s]" under the challenged jury instruction. ${ }^{169}$ Despite Justice Ginsburg's persuasive writing, the analysis in the majority opinion contains several errors that cast doubt on the efficacy of the decision.

\footnotetext{
162. See Norfolk S. Ry. Co. v. Sorrell, 549 U.S. 158, 178-79 (2007) (Ginsburg, J., concurring) (describing a "'slightest' cause" standard under FELA that is "far less exacting than 'proximate' cause").

163. McBride, 131 S. Ct. at 2634.

164. Sorrell, 549 U.S. at 172 (Souter, J., concurring).

165. McBride, $131 \mathrm{~S}$. Ct. at 2634.

166. Id. at 2638.

167. See id. at 2643.

168. Id. at 2641-43 (alternative opinion not joined by Thomas, J.).

169. Id. at 2641.
} 
1. Rogers Was Not an Authoritative Interpretation of Causation Under FELA

The first mistake the Court made in its analysis in McBride was the almost cursory conclusion that "Rogers is most sensibly read as a comprehensive statement of the FELA causation standard." contrary, Rogers should be understood in the context in which it was decided. Justice Ginsburg's declaration that it was a comprehensive statement of FELA's causation standard was grounded primarily in broad dicta regarding Congress's desire to provide enhanced protection to rail workers in enacting FELA. ${ }^{171}$ The majority opinion declares that "[o]ur subsequent decisions have confirmed that Rogers announced a general standard of causation in FELA cases." ${ }^{\text {,72 }}$ This broad and consequential conclusion was not directly supported by a single citation of authority. The only case arguably supportive of this proposition was Ferguson $v$. Moore-McCormack Lines, Inc. ${ }^{173}$ decided the same day as Rogers. ${ }^{174}$ In Ferguson, the Court stated-in a plurality opinion-that the "any part test" announced in Rogers was applicable to cases regarding the foreseeability between negligence and an injury. ${ }^{175}$ Not only is reliance on one plurality opinion from the same Court that so badly mangled causation analysis under Rogers unpersuasive, but a fair reading of subsequent FELA cases that applied proximate causation standards should have compelled a different outcome in McBride. The majority's blindness to these competing precedents is somewhat surprising given Chief Justice John Roberts's forceful explication of them in his dissent. ${ }^{176}$ Nevertheless, the Court's reading of Rogers as announcing the authoritative causation standard for FELA was unpersuasive because of its extensive reliance on dicta and unwillingness to distinguish competing precedents.

The facts in Rogers and subsequent decisions by the Supreme Court compel the conclusion that the majority's interpretation of Rogers hinged on careless dicta included therein. Although some lower federal courts

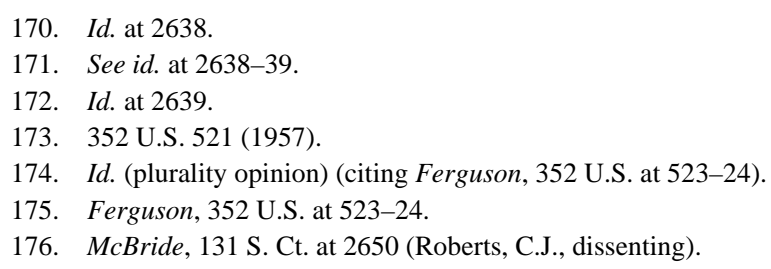


had relied on Rogers as being authoritative in this regard, ${ }^{177}$ the conclusion that Rogers interpreted FELA as abrogating common law conceptions of proximate cause is incorrect. In fact, the jury instruction supplied by the court in Rogers used the term "proximate cause," the Court not only quoted that language but "took no issue with [it] in this respect." ${ }^{\prime 79}$ Apparently, the Court had no problem reading a case that incorporated the term and concept of proximate cause as an authoritative pronouncement that the same case eliminated that concept's relevance in analyzing claims under FELA. This conclusion is further discredited by the numerous FELA cases-some pointed out by the dissent-that continued to use the phrase and concept of proximate cause, ${ }^{180}$ thereby disproving the Court's claim that the matter was decided in Rogers. ${ }^{181}$

The final omission in the Court's interpretation of Rogers was the factual scenario that gave rise to that decision. Although the majority portrayed Rogers as if stare decisis compelled the Court's result because it dealt with precisely the same matter, the Court failed to admit that Rogers arose in the context of a dispute about the applicability of the doctrine of contributory negligence-not proximate cause. ${ }^{182}$ As Justice Souter noted in Sorrell, the Rogers decision did not substantively change the law as it related to proximate cause. ${ }^{183}$ Justice Ginsburg had not accepted this view when it was proffered by Justice Souter in Sorrell, ${ }^{184}$ but because Rogers involved contributory negligence, it is fairly read as addressing only contributory negligence. Instead, the Court latched onto the broad dicta in Rogers and erroneously concluded that it reached, and abrogated, proximate cause. As Chief Justice Roberts rightly noted, Rogers only "clarified that, under a statute in which employer and employee could both be proximate causes of an injury, a railroad's negligence need not be the sole or last cause in order to be proximate."185

\footnotetext{
177. See id.

178. Rogers v. Mo. Pac. R.R. Co., 352 U.S. 500, 505 n.9 (1957).

179. McBride, 131 S. Ct. at 2649 (Roberts, C.J., dissenting) (quoting Norfolk S. Ry. Co. v. Sorrell, 549 U.S. 158, 176 (2007) (Souter, J., concurring)).

180. In dissent, Chief Justice Roberts listed eight state courts of last resort that explicitly continued to use "proximate causation" as a relevant standard in FELA cases. Id. at 2650.

181. See id. at 2636 (majority opinion).

182. See Rogers, 352 U.S. at 504 (rejecting the state court's assertion that Rogers's conduct "was the sole cause of his mishap").

183. See Sorrell, 549 U.S. at 174 (Souter, J., concurring).

184. See id. at 177-78 (Ginsburg, J., concurring).

185. McBride, 131 S. Ct. at 2648 (Roberts, C.J., dissenting).
} 
Thus, the initial —and maybe dispositive-error in the Court's analysis was its overbroad reading of Rogers. Unfortunately, it was not the only error.

\section{The Emphasis on FELA's Causation Language Ignores Relevant}

Parts of the Statute

Justice Ginsburg relied on FELA's language as a secondary point of emphasis in determining that common law proximate cause was no longer relevant in FELA cases. ${ }^{186}$ In emphasizing the statutory language as crucial to the Court's outcome, however, the majority exposed a dire flaw in its analysis. As a federal statutory tort, longstanding rules of interpretation compel the Court to start at the premise that Congress "adopt[ed] the background of general tort law."187 Accordingly, the Court should have assumed that common law proximate causation standards were incorporated into FELA unless the language of the statute provided otherwise.

The majority's conclusion that the "in whole or in part" language abrogated common law proximate cause is erroneous on two levels. First, that language was apparently included to abrogate the common law doctrine of contributory negligence, which is what the Court actually held-although, admittedly, with a great lack of clarity-in Rogers. ${ }^{188}$ Secondly, the statutory language in other parts of FELA explicitly abrogated common law elements that had previously prevented recovery to injured workers. ${ }^{189}$

This makes the conclusion that Congress sought to eliminate proximate causation standards without doing so explicitly a dubious one, unsupported by a fair reading of the statute. Instead of reading this much into congressional silence on the matter, the Court should have followed the standard rule of statutory interpretation whereby the Court will find proximate cause as an element of a statute even where it is not explicitly included. ${ }^{190}$ Instead, the majority broke the other way and concluded that Congress used the oblique "in whole or in part" language to abrogate a

\footnotetext{
186. See id. at 2636 (majority opinion).

187. Id. at 2645 (Roberts, C.J., dissenting) (quoting Staub v. Proctor Hosp., 131 S. Ct. 1186, 1191 (2011)).

188. Id. at 2647.

189. Id. at 2646.

190. See e.g., Dura Pharms., Inc. v. Broudo, 544 U.S. 336, 345-46 (2005) (requiring proof of proximate cause despite lack of explicit language in securities fraud statute).
} 
foundational element of common law torts. ${ }^{191}$ The determination is an erroneous interpretation of the statutory language employed given that Congress had expressly abrogated other common law doctrines. Congress clearly knew how to eliminate common law elements of which it disapproved, and the drafters' failure to do so with respect to proximate cause should have been dispositive in compelling the conclusion that proximate cause remained an element of FELA cases.

\section{The Majority Allowed Policy Goals to Outweigh Traditional Statutory Construction}

Policy considerations weighed heavily in the Court's ultimate conclusion. Specifically, a desire to see that the "'humanitarian' and 'remedial goal[s]'” of FELA ${ }^{192}$ were recognized and distaste for the concept of proximate cause were paramount in the Court's decision. ${ }^{193}$ Although these considerations may have a degree of relevance in deciding a case, the Court should not have allowed them to outweigh the history and text of the statute in arriving at its conclusion.

While Congress sought to expand the potential for carrier liability in passing FELA, it does not follow that it dispensed with common law proximate cause. The extralegal considerations for the plight of injured rail workers overly influenced the majority's position, leading it to ignore precedent and competing policy considerations. By reading an element of the federal tort out of the statute with scant legal support, the majority essentially adopted the position that the remedial and humanitarian goals of FELA should be pursued by any means necessary. While those goals have a limited degree of significance, the Court turned analysis of FELA on its head by concluding that a broad interpretation of the statute permitted —or even mandated — an erroneous legal conclusion. While some commentators have suggested FELA needs considerable change to cope with modern realities, ${ }^{194}$ any monumental changes-like eliminating a foundational element of a claim-should be left to Congress. Regardless of the humanitarian goals the majority concluded Congress sought to pursue with FELA, Congress provided a template for

\footnotetext{
191. See McBride, 131 S. Ct. at 2644 (majority opinion) ("[I]t is not error in a FELA case to refuse a charge embracing stock proximate cause terminology.”).

192. Id. at 2636 (alteration in original) (quoting Consol. R.R. Corp. v. Gottshall, 512 U.S. 532, 542-43 (1994)).

193. See id. at 2637 (criticizing use of the term "proximate cause" as shorthand for a concept).

194. See, e.g., Amato, supra note 3, at 132-36.
} 
those goals in the statute. The Court's majority ignored that template in large part based on policy considerations it believed Congress intended with FELA.

The majority's criticism of proximate cause as a legal concept also appeared to heavily influence the outcome in McBride. As Chief Justice Roberts noted, "[t]he plurality breaks no new ground in criticizing the variety of formulations of the concept of proximate cause.”195 Justice Ginsburg's scathing and mostly accurate criticism of proximate cause was misplaced. Proximate cause is admittedly a "deep and muddy water into which many men, wise and otherwise have ventured,"196 but for better or worse, it is the legal concept governing causation that has existed at common law for generations. ${ }^{197}$ It should not be done away with in an entire area of the law on the whim of five Justices. ${ }^{198}$ The academic merits of proximate cause are legitimate topics for scholarly debate, and perhaps eventually lawmakers-as opposed to judges-will follow their lead. In the meantime, however, judges should not allow their opinion of a certain longstanding legal concept to effectively overturn a well-established body of law.

\section{B. Chief Justice Roberts's Dissenting Opinion}

Chief Justice Roberts's dissent in McBride is more consistent with Rogers and follows Congress's intent in passing FELA more clearly than the majority's opinion. ${ }^{199}$ His dissent would have required that a proximate causation standard be included as an essential element in FELA cases. ${ }^{200}$ This position is supported primarily by two lines of reasoning. First, Chief Justice Roberts argues that proximate cause had always been considered an essential element of FELA claims, and without congressional action or judicial precedent to the contrary, it was inappropriate for the Court to eliminate this requirement. ${ }^{201}$ Accordingly, the dissent criticizes the majority opinion's willingness to read Rogers as broad enough to compel the elimination of proximate

\footnotetext{
195. McBride, 131 S. Ct. at 2645 (Roberts, C.J., dissenting).

196. Victor E. SChWARTZ, Et Al., Prosser, WAdE AND SChWARTZ's TORTS 303 n.1 (12th ed. 2010) (quoting White v. S. Ry. Co., 144 S.E. 424, 429 (Va. 1928)).

197. See McBride, 131 S. Ct. at 2645 (Roberts, C.J., dissenting).

198. The section of the opinion dealing with proximate cause only garnered four votes, thus limiting its effectiveness as precedent. Id. at 2642-43 (alternate opinion not joined by Thomas, J.).

199. See id. at 2644-52 (Roberts, C.J., dissenting).

200. See id. at 2645.

201. See id. at 2647-50.
} 
cause. $^{202}$ In a similar vein, Chief Justice Roberts dismisses Justice Ginsburg's argument that the matter was settled and proximate cause was not a foundational requirement in FELA actions. ${ }^{203}$ Although he concedes that most federal courts applied a significantly relaxed causation standard following Rogers, the dissent lists a multitude of states whose court of last resort explicitly required proximate cause. ${ }^{204}$ The dissent concludes by briefly responding to Justice Ginsburg's policy concerns. $^{205}$ Chief Justice Roberts expresses the concern that-although proximate cause is not a perfect gauge-it is "the vocabulary for answering such questions [of fault]" under FELA, and without it, potential defendants will be left to answer for injuries of a completely unforeseeable nature. ${ }^{206}$

Interestingly, Chief Justice Roberts's dissent in McBride closely followed Justice Souter's concurrence in Sorrell, which Roberts refused to join. If Chief Justice Roberts and Justice Kennedy-who joined Roberts in dissent-had joined Justices Souter, Scalia, and Alito in Sorrell, there would have been a five-justice majority to authoritatively establish that proximate cause was still required under FELA. Instead, with the retirement of Justice Souter in 2009, Justice Sotomayor joined the Court and became the fifth and decisive vote when the issue of proximate cause reached the Court in McBride. This will have profound consequences for railroad liability under FELA because, as described below, the Court's decision in McBride will significantly increase the potential for carrier liability. ${ }^{207}$ Although Chief Justice Roberts's dissent persuasively set forth this conclusion, the lack of a fifth vote for that position throws the carriers subject to FELA's causation standard on the mercy of Congress. ${ }^{208}$

At oral argument, Justice Scalia asked McBride's attorney to describe the proximate causation standard he would have the Court apply in FELA cases. ${ }^{209}$ Although McBride's counsel responded by advocating a "but-for plus" standard of legal causation, the dissent notes that the

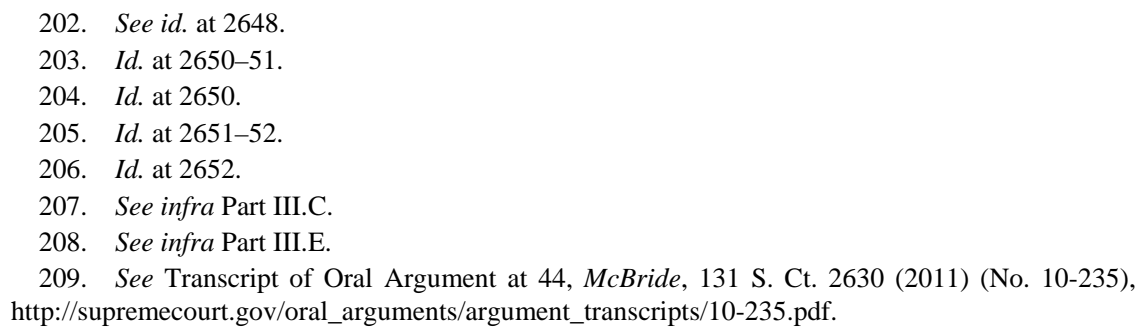


Court's opinion simply adopted a "but for" causation standard. ${ }^{210}$ Justice Scalia displayed his inclination to side with CSX by posing a series of hypothetical queries that would remind any lawyer of her first-year torts course. $^{211}$ Chief Justice Roberts followed up Scalia's hypothetical scenarios - which included snake bites and lightning strikes-by arguing that the Court's new standard is simply no standard, or in other words: "Caelum terminus est-the sky's the limit."212

\section{The Threat of Unlimited Liability for Carriers Under McBride's Standard}

\section{McBride Will Encourage a Flood of New FELA Claims}

The standard McBride effectuated will subject common rail carriers to the potential for nearly unlimited liability. If this prospect comes to fruition, it will not only have disastrous consequences for railroadseconomically, practically, and for their publicity-but the negative effects of subjecting a strong American industry to potentially enormous monetary liability will negatively impact the rest of the economy and American society. In response to this concern, Justice Ginsburg noted that the current standard is effectively the same one that has been applied in federal and most state courts since Rogers. ${ }^{213}$ The majority opinion noted that under this relaxed standard of causation, there are still adequate limits that prevent the railroads from being subjected to an undue or overly burdensome amount of litigation. ${ }^{214}$ The limitations cited by Ginsburg, however, were "common sense [and] FELA's limitations on who may sue... and for what [they may sue]." ${ }^{, 15}$ Moreover, the Court opined that the effect of the decision, if any, was to allow juries to make a more accurate finding of liability or no liability under FELA. ${ }^{216}$

Contrary to Justice Ginsburg's assurance, however, "but for” liability under FELA will impose costs on common carriers. ${ }^{217}$ This lax liability

\footnotetext{
210. McBride, 131 S. Ct. at 2647 (Roberts, C.J., dissenting).

211. Transcript of Oral Argument, supra note 209, at 30-31.

212. McBride, 131 S. Ct. at 2652.

213. Id. at 2640 (majority opinion).

214. Id. at 2644 .

215. Id.

216. See id. (discussing the negative consequences of adopting the charge to the jury sought by CSX, including the potential to mislead the jury).

217. Id. at 2645 (Roberts, C.J., dissenting).
} 
standard will encourage the plaintiff's bar to innovate new and inventive claims. For years, many litigants have tried to make claims for illnesses and conditions that have little or no obvious tie to their time as a railroad employee. ${ }^{218}$ While these claims have, for the most part, failed to gain traction, ${ }^{219}$ the explicit rejection of a common law understanding of proximate cause will encourage a new deluge of claims of dubious viability under prior law. Regardless of the majority's assurances that common sense and statutory limits will prevent litigants from bringing these claims, ${ }^{220}$ these limits will matter little when employees need only demonstrate an injury with the most tenuous link to the alleged negligence of their employer. For two primary reasons, McBride all but guarantees that American railroads will suffer a significant increase in liability and actionable claims under FELA.

The first reason potential liability under FELA will increase after McBride - an authoritative pronouncement on a federal question-is that the decision will now govern all FELA cases in every jurisdiction. Although the majority rightly pointed out that federal courts and the majority of state courts already applied a standard similar to-though less explicit than-that which will be instituted by McBride, ${ }^{221}$ jurisdictions that have previously concluded that proximate cause is an essential limitation on recovery under FELA may no longer require that element. Jurisdictions that had maintained the proximate cause requirement ${ }^{222}$ had good reasons for doing so, but after McBride these legal, economic, and policy considerations are no longer relevant. As explained below, allowing jurisdictions to formulate their own instructions and specific standards within a flexible proximate causation framework best comports with FELA's language and a common sense approach to tort law in a federal system. ${ }^{223}$

218. See, e.g., Carlisle v. Consol. Rail Corp., 990 F.2d 90, 97 (3d Cir. 1993) (considering a claim for negligent infliction of emotional distress arising from work-related stress), rev'd sub nom. Consol. Rail Corp. v. Gottshall, 512 U.S. 532 (1994).

219. See, e.g., Consol. Rail Corp. v. Gottshall, 512 U.S. 532, 554 (1994) (rejecting the Third Circuit's approach in Carlisle that allowed a claim for "the stresses and strains of everyday employment”).

220. McBride, 131 S. Ct. at 2641 (majority opinion).

221. Id. at 2640.

222. See, e.g., Ballard v. Union Pac. R. Co., 781 N.W.2d 47 (Neb. 2010) ("This court has stated that to recover under FELA, an employee must prove ... that the alleged negligence is a proximate cause of the employee's injury.”).

223. See infra Part III.D. 
McBride sounded the death knell for an effective proximate cause limitation in FELA cases. Particularly because-like many personal injury and negligence claims - many FELA cases are prosecuted under contingency fee arrangements, ${ }^{224}$ the elimination of a proximate cause requirement means that plaintiffs' lawyers will be more likely to take on cases that were previously much less likely to succeed. Justice Ginsburg cited several examples where the common sense of judges presiding over FELA cases prevented the most outrageous claims of a connection between employer negligence and injury from reaching the jury. ${ }^{225}$ What these examples fail to account for, however, are the significant burdens that defending frivolous claims place on railroads in terms of efficiency, time, and money. With an explicit charge from the Supreme Court that an injury is recoverable when it has only the most tenuous connection to alleged employer negligence, strike suits and questionable claims are nearly certain to result. The impacted railroads, moreover, will be likelier than ever to settle these claims for fear of allowing a jury to hear evidence and be instructed that the slightest relationship between negligence and injury will suffice. The Court's reassurances about the statutory limits on claims and the common sense of judges preventing this seemingly obvious outcome should be of little solace to railroads and the attorneys engaged to represent them.

\section{The New Claims Will Have an Enormous Economic Impact on}

Carriers and the Industry

McBride has the potential to significantly harm the railroad industry. Particularly in a time of economic uncertainty, introducing a radically expanded potential for liability into one of America's most important industries is dangerous. The unemployment rate in the United States currently hovers around $8 \%{ }^{226}$ The railroad industry is one of America's most important employment engines. ${ }^{227}$ The threat is real that the

224. See Daniel Saphire, FELA and Rail Safety: A Response to Babcock and Oldfather-The Role of the Federal Employers' Liability Act in Railroad Safety, 19 TRANSP. L. J. 401, 411 n.46 (1991) (implying that actions under FELA are primarily financed through contingency fee arrangements).

225. See McBride, $131 \mathrm{~S}$. Ct. at 2643-44 (majority opinion).

226. Economic News Release, Dep't of Labor, Bureau of Labor Statistics, Employment Situation News Release (Oct. 5, 2012), http://stats.bls.gov/news.release/archives/empsit _10052012.htm.

227. See Chris Bury, Railroads Adding 15,000 New U.S. Jobs, ABC NEws (Oct. 12, 2011, 3:12 PM), http://abcnews.go.com/blogs/business/2011/10/railroads-adding-15000-new-u-s-jobs/. 
increased likelihood of liability for entirely unforeseeable accidents and the need to settle strike lawsuits because of McBride's new permissive legal standard will significantly decrease the employment capacity of the rail industry. The railroads are already entities that Americansincluding billionaire investor Warren Buffett ${ }^{228}$-look to for economic stability in times of turmoil. The railroad industry is well suited to provide this stability because of its established role in the American economy, the inability to shift rail jobs overseas, and the continuing necessity to transport people and goods within an advanced economy. Imposing legally dubious, and economically disastrous, liability on the railroad industry will inevitably cause considerable harm to the very economy for which the industry would otherwise provide stability.

\section{A More Appropriate Standard of Causation Under FELA}

The Court in McBride called the proximate causation standard from Rogers a settled matter. ${ }^{229}$ As the dissent pointed out, however, the issue of the causation standard under FELA as interpreted by the Rogers Court was anything but clear. ${ }^{230}$ Thus, what causation standard Congress intended was a disputed issue-one that necessitated the Supreme Court's review in McBride. ${ }^{231}$ Instead of the standard announced in $M c B r i d e$, a more appropriate causation standard should be formulated for cases under FELA. FELA's causation language requires a successful claimant to establish proximate cause. $^{232}$ Within this proximate causation construct, a standard should be articulated that allows for jurisdiction-by-jurisdiction flexibility. Such legislation would permit each jurisdiction to decide along a continuum the necessary proof of causation for recovery, but it would also protect the railroads from "but for" causation liability - the very type of liability that poses a severe threat to the economic well-being of the rail industry in the wake of McBride.

\footnotetext{
228. Buffet Buying Burlington Northern Railroad, NBCNEWs.COM (Nov. 3, 2009, 3:16 PM), http://www.msnbc.msn.com/id/33599744/ns/business-us_business/t/buffett-buying-burlingtonnorthern-railroad/.

229. McBride, 131 S. Ct. at 2640.

230. See id. at 2650 (Roberts, C.J., dissenting) (noting that several states have rejected the notion that proximate cause should be "relegate[d] . . . to the dustbin" in FELA cases).

231. See Petition for Writ of Certiorari, supra note 49, at 5 (discussing the case's statutory background).

232. See supra Part III.A-B.
} 


\section{E. Congressional Action is Necessary to Amend FELA's Causation Language}

In large part due to the inability to move past partisan gridlock, Congress's approval ratings have sunk near all-time lows. ${ }^{233}$ Although the political parties are seemingly unable to agree on anything, codifying the standard articulated above $\mathrm{e}^{234}$-thus repudiating the Supreme Court's decision in McBride-is a legislative goal that should be politically acceptable to both parties. Congress should overturn the Court's decision with a law clarifying its intent, passed by simple majorities and signed into law by the President. A flexible causation standard that incorporates proximate cause will not only correct the uncertainties remaining after McBride, but will also improve rail policy in terms of efficiency and fairness. Because of the economic impact that the postMcBride causation standard under FELA will wreak on common rail carriers, ${ }^{235}$ members of Congress in both political parties should quickly act to clarify that proximate cause is a requirement for a successful claim under FELA.

Congress has a long history of legislating on issues that directly impact the railroad industry. These laws have been both for the benefit of the railroads and, like FELA, for the regulation of the industry. After McBride, congressional policy regarding the railroad industry has been distorted beyond recognition. Although Congress has repeatedly rejected calls to repeal FELA and create a workers' compensation-like scheme that compensates injured workers on a no-fault basis, ${ }^{236}$ lawmakers have repeatedly decided to maintain the current regime for recovery that is based on negligence and fault. ${ }^{237}$ The Court's decision in McBride treads dangerously close to entirely supplanting Congress's preferred policy of fault-based liability in favor of a no-fault-or at least no-cause-regime that does not have any limits on recovery. Although the majority argued that congressional silence following Rogers should be understood as

233. See Congressional Job Approval, ReAl ClEAR PolitiCs, http://www.realclearpolitics.com/ epolls/other/congressional_job_approval-903.html) (last visited Oct. 7, 2012) (indicating that $13.8 \%$ of Americans approved of Congress as of Oct. 7, 2012).

234. See supra Part III.D.

235. See supra Part III.C.2.

236. See Brief for Am. Train Dispatchers Ass'n et al. as Amici Curiae Supporting Respondents at 16-17, CSX Transp., Inc. v. McBride, 131 S. Ct. 2630 (2011) (No. 10-235), 2011 WL 719641, at *16-17.

237. See McBride, 131 S. Ct. at 2646 (Roberts, C.J., dissenting) (stating that Congress expressly eliminated certain common law doctrines in FELA while leaving proximate cause in place). 
acquiescence in the elimination of a meaningful proximate causation standard, ${ }^{238}$ the unsettled, inconsistent, and disputed meaning of FELA following Rogers should not be read so broadly. In the wake of McBride, however, it is imperative that Congress clarify its intent that liability in common rail carrier accidents be assigned only on the basis of fault and causation. By allowing McBride to stand, Congress has effectively permitted the judiciary to read the proximate causation standard out of the statute. In eliminating a meaningful causation standard, the Court has moved FELA in the very direction of no-fault liability that Congress has repeatedly rejected. Acquiescing in this shift is tantamount to deferring lawmaking authority regarding accidents in the railroad industry to unelected judges.

\section{CONCLUSION}

To ensure that railroads can continue to capture America's imagination while also fueling her economic growth, it is essential that common rail carriers not be subjected to "but for" liability due to a misinterpretation of an early-twentieth-century statute. Because the Supreme Court's erroneous decision in McBride will do just that, Congress must act to emphatically declare its intent that FELA include a proximate causation standard in accord with common law norms. The majority in McBride misinterpreted FELA's statutory language and Rogers's impact on its meaning. The dissent in McBride persuasively rebutted the majority's opinion and pointed out its most obvious shortcomings. But the dissent did not articulate an alternative standard for proximate cause, and Congress should act to reverse the majority's decision by clarifying that FELA does contain a proximate cause requirement. The amendment should also specify that the "new" proximate causation standard is one that should be applied flexibly on a jurisdiction-by-jurisdiction basis and in accordance with each jurisdiction's policy determinations and necessities. In so doing, Congress will ensure that one of its first and most successful employment safety statutes continues to successfully protect railroad employees without subjecting rail carriers to an unbearable level of liability. This task can be easily accomplished, and it will allow the railroad industry and its workers to chug forth in the Twenty-First Century.

238. See id. at 2640 (majority opinion). 